\title{
LA CONTRALORÍA GENERAL DE LA REPÚBLICA: SU SENTIDO HISTÓRICO*
}

\section{Alfredo Jocelyn-Holt Letelier}

Universidad de Chile

\begin{abstract}
Resumen: Esta conferencia analiza la Contraloría General de la República en tanto institución de la república, no del Estado. Para dichos efectos, se tiene en cuenta el contexto histórico en que fue creada: una dictadura militar y una creciente tendencia a querer fortalecer el presidencialismo mediante leyes no emanadas del Congreso. De ahí su papel fiscalizador, en especial su revisión de esta legislación (la "toma de razón") y de otros actos de gobierno, que es lo que le ha permitido consagrarse como un considerable poder constitucional.

Palabras clave: Contraloría General de República, institucionalidad, razón de Estado, “toma de razón”, dictadura, presidencialismo.
\end{abstract}

\footnotetext{
Alfredo Jocelyn-Holt Letelier (Santiago de Chile, 1955). Historiador. DPhil Oxford University. Profesor de la Universidad de Chile. Es autor de los libros La independencia de Chile. Tradición, modernización y mito (1991); Historia general de Chile (tres tomos); El peso de la noche. Nuestra frágil fortaleza histórica (1997); El Chile perplejo. Del avanzar sin transar al transar sin parar (1998). Coautor de: Historia del siglo XX chileno (2001); Documentos del siglo XX chileno (2001). Email: alfredo.jocelynholt@gmail.com

* Esta conferencia es una versión revisada de aquélla dada por el autor frente a la Contraloría General de la República, en conmemoración del aniversario n. ${ }^{\circ} 87$ de su fundación. El autor agradece al señor contralor, Ramiro Mendoza Zúñiga, su gentil invitación.
} 


\section{COMPTROLLER GENERAL OF CHILE: ITS HISTORICAL SENSE}

ABSTRACT: This conference examines the Contraloría General de la República as an institution of the republic, not of the state. To this effect it takes into account the historical context in which it was created: a military dictatorship and a growing tendency to want to strengthen the Presidency by laws not originating in Congress. Hence its comptroller role, especially the review of this legislation (the "toma de razón"), and of other acts of government, which has allowed it to become a significant constitutional power.

Keywords: Comptroller General of Chile, institution, reason of state, "toma de razón", dictatorship, presidential system.

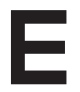

xponer sobre la significativa función que ejerce la Contraloría General de la República frente a quienes trabajan diaria y concienzudamente en ella puede resultar un tanto temerario, presuntuoso. Referirse a un asunto tan delicado - indagar el sentido, la razón de ser de esta institución - sólo puede justificarse porque la Contraloría es una entidad pública, de todos los chilenos, y como tal queda expuesta a ser analizada por cualquier ciudadano. La otra razón que podría aducirse es que nunca está de más oír reflexiones ajenas dichas de buena fe. La inmediatez de toda labor resta, a veces, perspectiva y contexto, que es lo único que nosotros los historiadores podemos ofrecer.

Lo primero que me llama la atención de la Contraloría es que es una institución. Esto, a primera vista, puede que parezca una obviedad, pero no si se lo piensa un poco. Las instituciones son creaciones, inventos (una palabra cada vez más en desuso, tal es la cantidad de inventos que se suceden hoy en día sin que podamos procesarlos). Obedecen las instituciones a una necesidad que antes no existía, por eso se las "crea". ${ }^{1}$ La Contraloría, de hecho, no es una corporación, no es un ente orgánico, una extensión natural del orden de las cosas y del gobierno. No son tampoco las instituciones "inmemoriales", como sí serían casi todas las corporaciones - la Iglesia, las fuerzas armadas, la univer-

${ }^{1}$ Sobre la idea de institución, véase, por ejemplo: Arnold Gehlen, "El hombre y las instituciones", 1960, conferencia reproducida en Ensayos de antropología filosófica, del mismo autor (Santiago de Chile: Universitaria, 1973), 94 y siguientes; también, Mario Verdugo M. y Ana María García B., Manual de derecho político. Tomo I (Santiago de Chile: Editorial Jurídica de Chile, 1979), 39 y siguientes. 
sidad-, tan antiguas éstas que uno tiene la impresión de que nunca fueron fundadas, de que siempre habrían existido; nosotros simplemente las habríamos recepcionado, se nos las habría "legado", serían un hecho dado de la tradición. Las instituciones son más recientes. En ese sentido discrepo de cierto propósito cada vez más frecuente de querer remontar los orígenes de muchas de nuestras instituciones al período colonial. Se ha tratado torpemente de hacerlo con la Universidad de Chile, mi universidad, remontándola torcidamente a la Universidad de San Felipe con la cual no tiene nada que ver (por eso se la eliminó y se creó "la Chile", una institución completamente distinta). Este ejercicio genealógico - una suerte de construcción de tradición ex temporeresulta patrimonialista, es decir, forzado y arribista, como cuando se confeccionan árboles de familia, fuleros los más. Está bien querer tener historia, pero hacerse de una historia prestada, imaginada, soñada, es como comprarse un retrato de cualquier individuo, a veces hasta desconocido, con pinta distinguida y elegante para hacerlo pasar como antepasado, cuestión que sucede bastante a menudo, es cosa de preguntarle a martilleros de casas de remates. Cuando se recurre a esa superchería de tradición se pasa por alto el por qué — en este caso la Contraloríase creó a comienzos del siglo XX, en esa época, no antes, aunque — por cierto- existen antecedentes, una serie de instancias cuyas funciones prefiguran a la actual Contraloría: los oficiales encargados de las Cajas Reales, la Real Audiencia en un momento, la Contaduría Mayor, la Dirección de Contabilidad General, el Tribunal de Cuentas... Prefiguran pero no devienen en esta instancia que nos interesa analizar. Nuestra actual institución es tan antigua o reciente como su logo muy art decó (que celebro que lo mantengan), su edificio (modernista y funcional) y su ubicación en medio del Barrio Cívico, lo que también nos dice mucho de ella y del conjunto de otras instituciones con las que comparte la plaza y se hermana.

El historiador Julio Heise relata una anécdota que, aunque se refiere al ente inmediatamente antecesor a la Contraloría (el Tribunal de Cuentas), ya anuncia una manera de entender la fiscalización de los actos de Estado, en especial del ejecutivo, y la independencia de quienes ejercían dicha función vis-à-vis La Moneda. Escribe Heise:

La autoridad moral del Tribunal de Cuentas permitió que la institución de los decretos de insistencia tuviera muy escasa aplica- 
ción entre los años 1891 y 1925. El Ejecutivo siempre acató las resoluciones del organismo fiscalizador. Arturo Alessandri Palma, a poco de asumir el mando (1920), quiso alejar de sus funciones a Joaquín Aguirre Luco, presidente del Tribunal de Cuentas. Para este efecto lo hizo llamar a su despacho manifestándole que no contaba con su confianza. El presidente del organismo contralor no renunció al cargo y se limitó a expresar que el Presidente de la República tampoco contaba con su confianza. Después de este incidente, Joaquín Aguirre Luco, con gran entereza y rectitud, continuó su misión fiscalizadora. El Tribunal de Cuentas objetó como ilegales cuatrocientos treinta y dos decretos en 1921, quinientos diez en 1922 y quinientos veintinueve en 1923 [nótese que las cifras van en aumento]. Estos decretos representaban un egreso ilegal de \$ 69.687.627 [una suma gigante para aquella época]. El año 1923 el señor Aguirre Luco se alejó temporalmente de la presidencia del Tribunal de Cuentas. ${ }^{2}$

Esta actitud frontal, sin cuidar los protocolos, en que un funcionario se enfrenta a la máxima autoridad del país, habría sido inconcebible en un organismo colonial (los funcionarios coloniales eran más obsequiosos); de haberse opuesto lo habrían hecho mucho más oblicuamente. ${ }^{3}$ En una república, en cambio, resulta más plausible una actitud frontal como la suya. Aunque esto tomó su tiempo, no fue de inmediato; una actitud así, al inicio del siglo XIX, también habría sido algo raro. Un abusivo uso de poder del Estado supone un Estado poderoso, y en el siglo XIX todavía el Estado era pequeño, bastante reducido, para nada lo que hemos conocido en menos de un siglo a esta parte. En efecto, la anécdota e incidente son propiamente del siglo XX. La actitud del funcionario - el señor Aguirre Luco - que se siente imbuido de una autoridad mandatada es muy tribunicia decimonónica. La desconfianza frente a un Presidente también, claro que respecto a un Presidente que clama por más poder, capaz incluso de querer pasar a llevar a empujones, a causa de su empoderamiento vía potestad administrativa y reglamentaria - lo cual supone un Estado cada vez más omni-acaparador-,

${ }^{2}$ Julio Heise, Historia de Chile. El periodo parlamentario 1861-1925. Tomo I. Fundamentos histórico-culturales del parlamentarismo chileno (Santiago: Andrés Bello, 1974), 318.

${ }^{3}$ Por ejemplo, el "se acata pero no se cumple", el incumplimiento de las leyes durante la colonia. Al respecto, véase: Mario Góngora, El Estado en el derecho indiano, época de fundación 1492-1570 (Santiago: Universitaria, 1951). 
calzando esto último, en cambio, más con el siglo XX que con cualquier otro período. La prepotencia soberbia y agresiva de Alessandri, por supuesto, es del XX. La desconfianza manifiesta de Aguirre Luco para con una persona como el "León" es todavía del XIX. El impasse, unos pocos años antes de que se creara la Contraloría, ilustra la necesidad de "inventarse" una solución institucional para salvaguardarnos de un Estado crecientemente arrebatador, entrometido y pulposo.

A lo que voy es que, quizá, debiéramos pensar la Contraloría como una de las pocas instituciones creadas durante el siglo XX, siglo por lo general despreciativo, deslegitimador de instituciones. No así el XIX, que es el siglo en que más instituciones se han establecido y han cundido. Pensemos en todas esas instituciones del siglo antepasado y su historia de descrédito posterior a lo largo del siglo recién pasado; concretamente, lo que ha estado ocurriendo ahora último con el Parlamento, los partidos políticos y, para qué decir, con la universidad nacional.

Decíamos que se trataría de una institución no colonial sino republicana. La insistencia en la ley, en la legalidad, es otra pista que nos permite reafirmar lo que hemos estado diciendo respecto a esta institución. Entendida, a su vez, la república como el gobierno de leyes antes bien, incluso, que de gobernantes (sean estos el pueblo o sus dirigentes), jefes u oficiales. Y la ley, por último, concebida como voluntad soberana, manifestada, prescrita conforme ciertas formalidades, concordante con las normas de máxima jerarquía dentro de nuestro ordenamiento, emanada de autoridad competente. Por eso también la reiteración de que la Contraloría controla, avala, la legalidad de los actos de la administración pública. Por lo mismo, ella no forma parte de la administración pública. Se asemeja, en su independencia y autonomía, a esos otros dos poderes, el legislativo y el judicial, columnas esenciales de la república. De ahí la actitud de don Joaquín Aguirre Luco frente a las pretensiones de superioridad de Alessandri. Si ni siquiera es un ente del Estado; no es la Contraloría General del Estado. Existió una Contaduría Mayor del Estado, suprimida definitivamente en 1883, y que es también un antecedente de nuestra Contraloría actual. Pero que se haya suprimido esta referencia al Estado en su nombre en 1927 me parece muy decidor, probablemente una corrección. La Contraloría no es "del Estado" ni incluso de Chile (como, de hecho, lo es el Ejército, la Armada, la Fuerza Aérea y Carabineros, todos "de Chile"). Es quizás uno de nuestros más graves problemas el que sigamos teniendo un 
Ejército de Chile y no de la República de Chile. Quienes concibieron la Contraloría, en cambio, tuvieron a bien la idea de que ésta fuese "de la República de Chile" - insisto - no del Estado ni de Chile a secas, lo que se presta para cualquier cosa. Me salto los detalles. La historia en este punto habla por sí sola.

¿Qué significaría, entonces, que no sea del Estado? ¿Por qué insistir sobre el asunto? Porque - si se me sigue en la lógica e interpretación que estoy tratando de argumentar - la Contraloría estaría fuera del alcance de las pretensiones monopólicas del Estado. Entendido el Estado, como en alguna medida lo concibe cierta doctrina, entre otros Max Weber, como una organización, un aparato que reclama y aspira para sí "el monopolio sobre la violencia legítima", ${ }_{4}^{4}$ pero también —y aquí expando la tesis de Weber- reclama y aspira para sí el monopolio normativo sobre la sociedad toda, también el monopolio fiscal, tributario fiscal. Me tendrán que perdonar algunos más "progresistas", pero tiendo a ver al Estado como un ente que, por definición, aspira a ser absoluto o totalitario (absoluto en los siglos XVII al XVIII, totalitario desde la Revolución Francesa en su fase de "terror" en adelante y ciertamente a lo largo del aterrador siglo XX, siglo de fascismos, comunismos, socialismos e incluso de totalitarismos algo más "suaves", pero no por eso menos todo abarcadores y monopólicos). Admito que es una definición liberal a la que recurro, pero también, y esto no es menor, una definición "institucional", sospechosa de este afán potencialmente totalitario del Estado. Es decir, una definición más histórica que filosófico-política, atendiendo no a las infinitas y posibles elucubraciones que podríamos contemplar y sostener, sino a la trayectoria liberal, republicano-liberal concreta, que ha guiado, por lo general, nuestra praxis política desde 1810 en adelante. Admito que es una concepción y praxis que otras líneas en competencia — posicionamientos antiliberales - han amenazado e intentado desvirtuar, sabotear, revolucionar, deconstruir, pero que, a pesar de todo, persiste — gústenos o no- gracias precisamente a la larga historia institucional decimonónica de este país y que subsiste - mal o bien, anacrónicamente o no- hasta nuestros días. Uno de esos capítulos, uno de esos hitos institucionales, es el de esta Contraloría "de la República" como he estado sosteniendo. Su sola existencia pretende-

${ }^{4}$ Max Weber, Economía y sociedad. Esbozo de sociología comprensiva (Ciudad de México: Fondo de Cultura Económica, 1944), 667 y 1.056. 
ría limitar al Estado. Se trataría, pues, de un ente público que no es lo mismo que estatal o meramente fiscal, términos que con demasiada ligereza se equiparan no siendo sinónimos; lo equiparan incluso personas no vulgares, gente supuestamente docta, en esto, errada.

Otro signo de contemporaneidad de esta institución-creación es la "toma de razón" (curioso fraseo), una de las funciones primordiales de este cuerpo fiscalizador, que confiere una presunción de legalidad, en el fondo, a los decretos con fuerza de ley y a los decretos supremos, es decir, a gran parte si es que no al grueso de la acción del Estado; una "legislación" discutible toda vez que supone una delegación de funciones legislativas, propias del poder legislativo, al ejecutivo (como es el caso de los decretos con fuerza de ley), cuando no una usurpación que se ha ido dando por parte del Estado constructivista y vigilante respecto a los otros poderes y la sociedad en general, tolerada irresponsablemente por el resto. Y, quizá, si nos hemos de poner puristas, una apropiación de facultades legislativas que serían originalmente parlamentarias. Que, así y todo, sin embargo, la Contraloría entra a avalar. En el fondo, la Contraloría viene a remediar, a subsanar, elevando estos meros decretos a la más noble calidad de leyes, porque, después de todo, vivimos en una república, bajo un gobierno de leyes. Dicho de otro modo, la Contraloría controla la legislación del Estado a la vez que le confiere un valor de ley, en un sentido más propiamente republicano, a un nuevo tipo de legislación, más expedita, menos consensuada, menos discutida, arbitraria y eficaz (quizá hasta fáctica), siendo este tipo de "legislación", como ya he dicho, el grueso de nuestra normativa por lo demás. Es justamente la aparición de este nuevo tipo de legislación, a la vez que de un Estado, una maquinaria estatal crecientemente potente, lo que, en buena medida, explica el surgimiento de la Controlaría. Reitero: esta situación es inédita. Sólo a comienzos del siglo XX, no antes, se hace imperativa la función fiscalizadora para este nuevo tipo de corpus legislativo y el ente del cual emana: el Estado. Una nueva situación exigía una nueva institución.

La "toma de razón" de este tipo de normas es posible que sea, incluso, la contrapartida de la "razón de Estado". Me costó mucho entender qué era la "razón de Estado"; finalmente, después de darle muchas vueltas, llegué a la conclusión de que la razón de Estado no es otra cosa que el reconocimiento que hace el Estado de que no tiene la razón, que sólo posee fuerza bruta, y por ende precisa camuflar su arbitrariedad con lo más presentable, lo más potable que tiene a mano, que es la 
invocación, vacua por cierto, a la razón. La razón de Estado es la reverencia discursiva, el homenaje hipócrita que rinde el Estado a la virtud del derecho. ${ }^{5}$ La toma de razón, en cambio, no es insincera. Si hemos aceptado que el Estado va a legislar y nos va a normar (no sólo ejecutar las leyes emanadas del poder legislativo) se precisa de una legitimidad externa, una legitimidad "legal" que sea ajena a la mera fuerza, que es lo que esgrime el Estado. Y es esa legitimidad "legal" la que le presta y confiere la Contraloría a buena parte de los actos de Estado. De lo contrario, nos regiríamos por meros estados de excepción, por puras razones de Estado. Cuando se estaba creando la Contraloría — en los años 20 aproximándonos a los 30 - el temor a esta posibilidad y escenario radical, el querer someter a sociedades enteras a vivir y funcionar en un estado enteramente de excepción, no era del todo disparatado.

El sesgo de este tipo análisis es histórico. Me interesa la institución muy especialmente por su arraigo a un tiempo, a condiciones, a necesidades, de un período específico. Me atrevo a sostener que es ahí, no en otro antecedente, donde cabe encontrar buena parte de su sentido, su explicación, su razón de ser.

Si hilamos más fino en los orígenes históricos de la Contraloría, me llaman especialmente la atención dos aspectos concretos: uno, el referente de la Misión Kemmerer que antecede a la creación de la Contraloría, y dos, que su fundación nos remita a una dictadura, la de Carlos Ibáñez, es decir, a un estado de excepción. Esto, más que una curiosidad histórica, se trataría de aspectos cruciales que exigen explicación, de lo contrario no se entiende nada de nada.

La creación de la Contraloría sólo en parte responde a la necesidad de concentrar todas las atribuciones fiscalizadoras en una sola entidad, cuestión que se venía planteando desde bastante tiempo antes. Las recomendaciones que hiciera la Misión Kemmerer, presidida por Edwin Walter Kemmerer, economista de Princeton University, y contratada por el gobierno de Chile - recomendaciones concordantes con esta necesidad de fundir varias instancias fiscalizadoras previas - obedecen a un proceso continental que no se limitó sólo a Chile. Kemmerer - “the Money Doctor in the Andes" como lo llamara el historiador Paul Drake

${ }^{5}$ Véase mi libro El peso de la noche. Nuestra frágil fortaleza histórica (1997, reimpreso en Santiago: Debolsillo, 2014), 169-171. Sobre la idea de "razón de Estado", consúltese: Friedrich Meinecke, La idea de razón de Estado en la edad moderna (1952, reimpreso en Madrid: Centro de Estudios Constitucionales, 1983). 
en su libro de 1989 — ${ }^{6}$ aconsejó y estuvo en diversos otros países latinoamericanos: amén de Chile, en Colombia (ya antes) y en Ecuador, Perú, Bolivia, México y Guatemala. Como bien dice la historiadora Sofía Correa:

Las reformas propuestas por Kemmerer se entienden en función de la necesaria inserción de los países sudamericanos en el mercado financiero y comercial de los Estados Unidos después de la Primera Guerra Mundial, de modo que en cada uno de estos países hubo reformas monetarias (introducción del padrón oro), tributarias e institucionales (tales como la creación del Banco Central, la Superintendencia de Bancos y la Contraloría General de la República) que seguían el modelo de los Estados Unidos y aseguraban a sus inversionistas un marco de confianza para hacer negocios, a la vez que constituían un hito en la modernización institucional latinoamericana y posibilitaban la captación de créditos norteamericanos. ${ }^{7}$

Dicho de frentón, los norteamericanos no estaban dispuestos a canalizar platas vía empréstitos blandos directamente al Estado o a través del Estado sirviendo éste de aval, a no ser que el Estado chileno manejara en forma correcta, ordenada y con probidad suficiente sus cuentas públicas. En otras palabras, lo que vino a decirnos Kemmerer es que los Estados Unidos y sus inversionistas no estaban por tratar con cualquier Estado, por eso éste debía ponerse al día, cuadrarse y comportarse de acuerdo con los estándares más de punta en cuanto a fiscalización: los de los Estados Unidos y Gran Bretaña por aquella época.

Esta sugerencia, un tanto imperativa ("quieren créditos, bueno, aténganse a nuestras condiciones"), va a ser aún más impositiva e ineludible para Chile con posterioridad a la Gran Depresión, unos años después del establecimiento de la Contraloría en Chile. También la necesidad de que la Contraloría produjera informes estadísticos y financieros que permitieran al gobierno planificar y ejecutar sus políticas económicas y otorgaran la información indispensable para atraer a los inversionistas extranjeros. En consecuencia, la Contraloría apuntará a

${ }^{6}$ Paul W. Drake, The Money Doctor in the Andes. The Kemmerer Missions, 1923-1933 (United States of America: Duke University Press, 1989).

${ }^{7}$ Sofía Correa Sutil, "La Contraloría General de la República", texto inédito. 
varias líneas - creditworthiness (solvencia), probidad y planificaciónestimadas fundamentales para que un Estado como el de Chile se modernizara y fuese reconocido como contraparte de flujos de dineros que se van a tornar cada vez más frecuentes y cuantiosos.

No se les escapará — supongo- ciertas similitudes, analogías, afinidades de una propuesta como ésta de parte de los Estados Unidos con la de otras "misiones consultivas" que habríamos de tener décadas después. Estoy pensando, desde luego, en la Misión Klein-Saks de 1955, que también involucrara a economistas norteamericanos, también curiosamente en un gobierno de Carlos Ibáñez (aunque no en dictadura), y sirviera de antecedente clave del monetarismo y neoliberalismo tipo "Chicago" de nuestros días. ${ }^{8}$ Evidentemente, hay que poner ojo en este tipo de comisiones de expertos extranjeros cuyas consecuencias resultarán decisivas a lo largo del siglo XX chileno. La Contraloría General es parte de una nueva concepción de Estado, atendida la participación de ese Estado en un mundo crecientemente interrelacionado y pauteado desde fuera. No digo esto en son de crítica — no soy izquierdista ni crítico del capitalismo, y menos un nacionalista de derechas o izquierdas-, lo planteo simplemente en función del entramado de relaciones e interconexiones que van a suponer para Chile su participación en un mapa económico y político más amplio a partir de las primeras décadas del siglo pasado.

El otro aspecto que me llamaba la atención — recordarán- era que esta institución haya sido creada durante una dictadura. Paul Drake, en su libro sobre Kemmerer, hace especial hincapié en que la idea de una Contraloría existía desde 1925 y 26, pero la iniciativa estaba siendo torpedeada, saboteada, frenada por el Congreso, reacio a darle curso. Sólo cuando Ibáñez en 1927 se ha hecho del poder casi total e impone la fuerza, ésta se hizo posible. ${ }^{9}$ Sin apoyo de una dictadura lo más probable es que la iniciativa no hubiese sido posible. Ahora bien, resulta un tanto paradójico que una dictadura, es más, una dictadura militar con visos totalitarios la materializara. Uno podría suponer que una dictadura quisiera desembarazarse de limitaciones a sus facultades

${ }^{8}$ Véase al respecto el trabajo de Sofía Correa, "Algunos antecedentes históricos del proyecto neoliberal en Chile (1955-1958)", Opciones 6 (1985): 106146, doi: historiapolitica.com/datos/biblioteca/scorrea.pdf/

${ }^{9}$ Drake, The Money Doctor, 103. 
que ésta implicaba. Evidentemente, el asunto es bastante más complejo. Mencioné anteriormente que la Contraloría avalaría un nuevo tipo de legislación por decreto elevando gran parte de esta actividad a calidad de "leyes". No quisiera dar a entender, en ningún caso, que la Contraloría por lo mismo estaría avalando a una dictadura ni mucho menos. El aval en última instancia es respecto al Estado y presupone - también he argumentado - una corrección o remedio al problema del origen de estos decretos y normas. Que se tratara de una dictadura no obsta que se trate también de un presidencialismo y de una creciente estatocracia; por consiguiente, que hayamos estado en medio de una dictadura no altera mayormente una tendencia - la del presidencialismo - que se va a acentuar dentro o no de un régimen de excepción. Es más, suele decirse (y correctamente) que ese primer gobierno de Ibáñez sería el creador, el que organiza el aparato estatal que se mantiene hasta nuestros días. Impugnar las creaciones bajo dictadura es algo que, de hecho y en la práctica, no ha ocurrido en este país, tanto entonces como también respecto a la dictadura reciente. En efecto, la dictadura e Ibáñez cayeron el '31, sin embargo, la Contraloría continuó. Podrá haber sido creada en dictadura, pero sobrevivió a la dictadura: ése es el punto en el que hay que detenerse. Adicionalmente, es conocido el argumento de que las dictaduras no son incompatibles con los regímenes republicanos. Esto puede que ofenda nuestras actuales sensibilidades políticamente correctas, pero históricamente hablando lo que digo no es del todo impropio. La historia europea, desde Roma, pasando por el período del Renacimiento e incluso con posterioridad (no olvidemos que la Commonwealth de Oliver Cromwell fue tan dictatorial como republicana), apoya lo que estoy argumentando. Por último, hay suficientes antecedentes de que Ibáñez no quiso hacer un gobierno militar, que "presidencializó", civilizó, su mandato, de modo que el suyo no fue tan caudillista ni despótico-militar después de todo. ${ }^{10}$ Hans Kelsen, por su parte, sostuvo que la Constitución de 1925 habría sido, técnicamente hablando, una "dictadura legal" y en esta época estábamos, vivíamos — haya habido o no una dictadura - bajo un orden constitucional. Hago la salvedad,

${ }^{10}$ Para una línea interpretativa en esa dirección, véase: Frederick M. Nunn, Chilean Politics, 1920-1931. The Honorable Mission of the Armed Forces (New Mexico: Albuquerque, 1970); y del mismo autor, The Military in Chilean History. Essays on Civil-Military Relations, 1810-1973 (New Mexico: Albuquerque, 1976). 
no para relativizar o exculpar ni el período dictatorial ni sus creaciones institucionales, sino para complejizar la naturaleza de nuestras "repúblicas", cuestión que desde una perspectiva histórica, que es desde donde me manejo, admite matices que quizá desde otras perspectivas - filosófico-políticas, por ejemplo- resultan más inadecuados. Pienso, en todo caso, que el cargo de servilismo y obsecuencia es más aplicable al poder judicial que a una institución como la Contraloría, incluso durante la dictadura más reciente. Que yo sepa, el cargo o imputación no se ha hecho respecto a la Contraloría, como sí ha ocurrido con los tribunales. Por algo será. Es más, se podría argumentar que la Contraloría fue clave para evitar que la Unidad Popular se convirtiera en una dictadura socialista popular. También éste es un tema apasionante que daría para mucha discusión adicional.

Pero volviendo a algo más aterrizado, parece claro, sin embargo, que la Contraloría fortaleció al gobierno y al Estado. Y eso, también, puede que explique por qué un gobierno fuerte, no un congreso parlamentarista, haya terminado aceptando una iniciativa como la que estamos intentando comprender en su tiempo y en sus circunstancias. Una de las particularidades de nuestra Contraloría, en contraste con otras contralorías de otros países latinoamericanos, también fruto de las recomendaciones de Edwin Walter Kemmerer, es que sirvió para centralizar e imprimir un carácter más unitario al Estado chileno; tendencia muy "chilena" por lo demás. El punto está argumentado en el libro de Paul Drake. ${ }^{11}$

Otro aspecto al que me gustaría referirme es respecto a la importancia de las personas en las instituciones. Se suele afirmar que las instituciones son impersonales. Lo son más que aquellos organismos que suponen, a veces, una membresía funcional, es decir, miembros que por derecho propio, por nacimiento, por estatus social o tradición, les correspondería participar en dichas instancias (por ejemplo, las corporaciones, las universidades, los senados o cámaras altas, como la Cámara de los Lores británica, en fin, antiguas corporaciones que - insisto - no serían instituciones y, por de pronto, las aristocracias no son impersonales). Con todo, es evidente que, incluso en las instituciones modernas, más igualitarias o simplemente meritocráticas en su reclutamiento, la persona que ha de dirigir, y a veces encarnar la idea de la institución, es

${ }^{11}$ Drake, The Money Doctor, 104. 
o puede ser decisiva, emblemática incluso. La mejor ilustración a lo que me estoy refiriendo es el caso de la universidad, la universidad moderna ya no tradicional, como entre nosotros la Universidad de Chile. Evidentemente, el solo hecho de que su historia abarque desde Andrés Bello a Víctor Pérez Vera nos está diciendo muchísimo sobre lo que ha estado pasando con nuestra universidad. Obviamente, la universidad de Bello no es la universidad de Pérez. Algo ha ocurrido, algo se ha descompuesto y ha ido degenerándose en el camino. Las personas son clave en tanto sintomáticas del tipo de institución que estamos tratando en distintos períodos históricos. Pues bien, no deja de asombrarme la continuidad de un cierto tipo de funcionario, también los jefes que han presidido esta institución: los señores contralores y sus equipos. Un alcance como éste que estoy haciendo requeriría más trabajo; habría que hacer un estudio prosopográfico a partir del corpus de funcionarios y autoridades, estudio que no existe, que yo sepa. Con todo, me atrevería a afirmar que, en general, los funcionarios de la Contraloría se distinguen por su solvencia profesional (son muy buenos abogados, tienen que serlo), por su vocación pública, su transversalidad política cuando no su agnosticismo político, que en un país como el nuestro no deja de ser notable, y ciertamente por su bajo perfil, en sentido positivo, faltos de estridencias, de figuración, escándalos, cuestionamientos y acusaciones. Hay excepciones, por supuesto, pero la regla general prestigia a la institución.

Comenzamos mencionando la figura, el temple y desplante de don Joaquín Aguirre Luco, nada menos que frente a Alessandri. Esta tipología de funcionario viene de atrás, precede a la creación de la institución. En efecto, ya antes de la aprobación de las propuestas de Kemmerer nos encontramos también con don Julio Philippi, quien, en su calidad de superintendente de bancos, revisó dichas proposiciones. Razonable elección. Los planes de Kemmerer se centraban en temas económicos. Además, quien pudiera controlar los bancos bien podía disponer de experiencia útil para también intentar controlar otros actos y actividades, esta vez, del Estado. Pablo Ramírez Rodríguez, el primer contralor, es uno de los personajes más notables, fascinantes y desconocidos de la historia política de Chile. Se ha afirmado que es el creador del Estado moderno de Chile, sin embargo, sabemos poco de su vida y carácter en términos fehacientes, lo que se ha prestado para todo tipo de denostaciones y chismes sobre su persona. Gonzalo Vial, historiador copuchento y obseso, metiche sobre la vida privada de los actores históricos, ha 
escrito parrafadas enteras dejando caer insinuaciones odiosas sobre Ramírez, motivadas seguramente por su descollante defensa del laicismo y la secularización. ${ }^{12}$ Ramírez era una persona reservada, compleja, en lo personal, fácil blanco de insidias por lo mismo. Ramírez podrá haber sido uno de los hombres más poderosos que ha habido en este país, pero guardaba, a final de cuentas, cierto bajo perfil.

Ha habido contralores que perduraron tres períodos presidenciales (los casos de Enrique Bahamonde, Héctor Humeres y Osvaldo Iturriaga, este último contralor por casi veinte años). Estas largas permanencias hoy en día no están autorizadas, pero las hubo en su momento, y marcaron y confirieron un sentido de continuidad que pareciera ser un distintivo muy propio de las instituciones más venerables. Éstas se sostienen en el tiempo en la medida en que sus funcionarios y directivos permanecen ejerciendo sus cargos. Hoy en día esta idea, este criterio, es anatema, se le reprocha. Pero también es cierto, y quizá por lo mismo, que las instituciones (cada vez más carentes de soporte personal) se han estado debilitando. Hay dos casos relativamente recientes que podrían llamar la atención por lo discutibles: el de Sergio Fernández — desde luego, por cómo llegó al cargo de contralor general, y también por sus actuaciones como ministro, especialmente del Interior-y el caso de Mónica Madariaga. Ambos personajes, excepciones, o, mejor dicho, ambos personajes convertidos en excepciones, por lo mismo que uno asocia con el cargo de contralor general de la república todas esas otras virtudes que ellos parecieran desmentir. A lo que voy es a lo que decía anteriormente: la regla general es de un funcionario no protagónico, no comprometido políticamente, de bajo perfil aun cuando pueden ser o hayan sido poderosísimos, de óptimo rigor y desempeño profesional. $\mathrm{Ni}$ Fernández ni Madariaga calzan con ese prototipo.

Una última caracterización de la Contraloría obliga a visualizarla en su dimensión constitucional. Ya la representación de la inconstitucionalidad y de la ilegalidad de ciertas medidas ejecutivas presuponía la necesidad de elevar la institución a rango constitucional. Este atributo

12 Véanse las siguientes referencias a Ramírez en Gonzalo Vial, Historia de Chile (1891-1973). Vol. II (Santiago: Zig-Zag, 1983), 666; Vol. III (1987), 93, 97, 163-168; Vol. IV (1996), 121, 123, 130, 138, 141, 154, 187-193, 207, 232, 265, 279, 305, 378; Vol. V (2001), 14-15, 159. Recientemente ha aparecido un estudio biográfico sobre Pablo Ramírez, de Jaime Esponda: Pablo Ramírez. El chileno desconocido (Santiago: RIL, 2014). 
se consagra en 1943, presumo que en parte debido al crecimiento que hacia esa década va adquiriendo el Estado. Si la Contraloría había de controlar al Estado, era imperioso que ella tuviera reconocimiento por parte de la máxima instancia legal de este país (la Constitución), de lo contrario se habría tratado de una institución desproporcionadamente débil frente a un Estado y un presidencialismo cada vez más entrometidos y acaparadores de prerrogativas. Fue sensato proveerle y mantenerle en ese carácter y disposición. De hecho, la Contraloría sobrevive a la Constitución de 1925, cuestión que hay que tener en cuenta; no es que quiera alarmar a nadie, pero igual me parece sensato precaverse ante cualquier intento de modificar esa conquista institucional. Lo señalo porque, de llegar a prosperar — ojalá que no — cierta predisposición radical por hacer borrón y cuenta nueva constitucional "por las buenas o por las malas" (tengo en mente a los Fernando Atria de este mundo en que vivimos), es aconsejable estar, a lo menos, atentos y en guardia. Hay mucho en juego. He escuchado, en estos días, la tesis que afirma que la opción "asamblea constituyente" sería, además de contraria y adversa respecto al Congreso y a los partidos, un intento para reforzar las prerrogativas del ejecutivo, y además de un ejecutivo afín a cierto populismo político presidencial (lo más preocupante). Si fuese efectivamente ése el caso estaríamos ante un intento encaminado a socavar equilibrios constitucionales establecidos desde hace décadas, antes incluso del 73. La facultad de revisar y fallar sobre la constitucionalidad de las acciones ejecutivas ha terminado por hacer de la contraloría chilena la contraloría más poderosa de las que surgieron del modelo inicial propuesto por Kemmerer. Según Paul Drake, Ibáñez convirtió a nuestra Contraloría en un verdadero cuarto poder constitucional. ${ }^{13}$ Cabe preguntarse si ello se va a mantener o no en un escenario constitucional como el que algunos vaticinan. Presumo que los militares están atentos. No tendría por qué no estar atenta también, y con mayor razón, una instancia legal como la Contraloría.

Mi insistencia en la necesidad de atender al "sentido" de esta institución, como también de otras (la universidad es la institución que mejor conozco y la que más me aflige), responde a una preocupación incluso mayor a la que puede llegar a producir la mera angustia política en esta época de creciente confusión. Vengo trabajando desde ya un

\footnotetext{
${ }^{13}$ Drake, The Money Doctor, 104.
} 
tiempo en una obra histórica de varios volúmenes, una propuesta de Historia general de Chile. ${ }^{14}$ La lógica central que ordena este trabajo es identificar en lo posible los distintos sentidos de la historia de este país. Sostengo, a diferencia de la escuela historiográfica liberal decimonónica, que Chile tiene varios otros "sentidos de la historia" que el que esa historiografía ofrece. Según los liberales, Chile se encaminó de una época de las tinieblas, una suerte de medioevo "colonial" y tenebroso, a una época de luz gracias a ese gran hito que fue la Independencia y que por último nos desembocó en el objetivo final de esta historia: la aparición y creación del Estado nacional. La tesis, aunque potente, elocuente y convincente, es peligrosa, además de que probablemente falsa en un punto al menos. Suponer que Chile se ha estado encaminando a un solo objetivo final peca de monista. Nuestra historia es más rica, más diversa, más plural. Chile es más plural, manifiesta múltiples sentidos, no sólo uno. Hemos tenido sentidos épicos (por ejemplo, lo que se deduce de un gran poema como La Araucana), sentidos utópicos (leyendas como la de los césares perdidos y de lugares que entrañarían un supuesto destino manifiesto como la Patagonia o nuestra proximidad cosmográfica con el "fin del mundo" antártico) y también sentidos políticos (como la vieja idea republicana en su versión no necesariamente revolucionaria, sino institucional). Es en función de esta lógica y sentido republicano que habría que situar una institución como la Contraloría, más aún si me aceptan, o al menos aceptan pensar que una institución como ésta, al igual que otras (como el Parlamento), pueden servir de antídoto frente a la amenaza "filantrópica", ogro filantrópica, ${ }^{15}$ en que consiste la oferta estatal. El problema con la tesis historiográfica liberal es que, no siendo suficientemente pluralista, termina resultando una argumentación a favor de un estado-nación, pero también de un aparato de poder, no así a favor de una limitación de poder. Todo lo que signifique aumentar poder - ergo, el Estado - es de cuidado. Todo lo que sirva para cautelar el poder, es decir, las leyes y la legalidad, debiera provocarnos una cautela mínima, sensata y razonable. Tiendo a ver a la Contraloría en ese contexto y en ese predicamento. Por eso su constitucionalidad,

${ }^{14}$ Alfredo Jocelyn-Holt Letelier, Historia general de Chile. Vol. I (Buenos Aires: Sudamericana, 2000); Vol. II (Santiago: Sudamericana, 2004); Vol. III (Santiago: Sudamericana, 2008).

15 Octavio Paz, El ogro filantrópico (Ciudad de México: Editorial Joaquín Mortiz, 1979). 
su función fiscalizadora, guardián de límites para con el poder, son tan acertadas, aunque algo frágiles y vulnerables.

Celebré anteriormente que se mantuviera el logo de la Contraloría. Quien diseñó ese logo, esa representación simbólica e iconográfica, sabía a lo que estaba refiriéndose. Muestra a una matrona sentada en un tribunal, con atributos reales (la diadema y lo que parece ser un cetro), también el libro donde se escribe (en este caso) la ley, la norma válida, legítima, exenta de vicios que pudieran anularla. En un viejo libro, de allá por 1593, el famoso Iconología de Cesare Ripa, suerte de catastro de representaciones clásicas simbólicas para uso de diseñadores, su autor registra varias semblanzas análogas al logo de la Contraloría (los paréntesis son míos):

Ley: Envejecida Matrona de venerable aspecto que se sienta majestuosamente sobre un tribunal, tocando su cabeza con una Diadema [adorno femenino de cabeza, en forma de media corona abierta por detrás que se usa como símbolo de autoridad] y sosteniendo un cetro [vara, bastón o insignia de mando, generalmente de materiales preciosos, que exhibían emperadores y reyes como signo de su autoridad] con la diestra, en torno al cual se ha de ver un cartel con la siguiente leyenda: Iubet et prohibet [ordena y prohíbe]. Sobre la rodilla izquierda ha de pintarse un libro levantado y abierto, en cuyas páginas ha de estar escrito: In legibus Salus [En las leyes está la salvación] [...].

Puede la Ley semejarse a una venerable Matrona; pues así como ésta gobierna y conserva la familia, así también las leyes conservan y gobiernan la República [...].

Aparece sentada en un estrado o Tribunal, porque es desde ellos, y en la posición que decimos, como deben sentenciar los Juristas, juzgando doctamente sobre el contenido de las Leyes.

Lleva la diadema en la cabeza para mostrar su santa determinación; y en verdad que con razón se puede calificar de santa la imagen de la Ley, pues ésta viene a ser causa y motivo de que se ejerza el bien y que se evite el mal [etc., etc., etc.]. ${ }^{16}$

Muchas gracias por la paciencia y atención. EP

${ }^{16}$ Cesare Ripa, Iconología. Vol. 2 (Madrid: Eitorial Akal, 1996), 15. 